\title{
State Legislative Response to Direct Democracy and the Politics of Partial Compliance
}

\section{Kathleen Ferraiolo}

Over the last quarter-century, direct democracy has played an increasingly important role in state politics and policy. While limited attitudinal data show high levels of legislative approval for direct democracy, the most prominent piece of behavioral scholarship concludes that California legislators often attempt to steal the initiative by displacing ballot measure content and preventing full implementation. Results from an original web survey indicate that Oregon lawmakers are cautiously supportive of the initiative process and identify the conditions under which they support changes to voter-ratified bills. Case study evidence shows how legislators use their power to amend successful initiatives to clarify and improve flawed measures. I argue that institutional rules governing the initiative amendment process in Oregon allow legislators to engage in partial compliance while preserving voters' core ideas. By drawing on new data sources and analyzing both behavior and attitudes, the findings shed new light on when, how, and under what conditions state government actors interfere in the initiative process and offer an important correction to the literature on legislative response to direct democracy.

Over the last quarter century, direct democracy - the process by which voters go to the polls to enact policy largely independent of state legislatures - has played an increasingly prominent role in state politics and policymaking. With the explosion of ballot initiative activity since the passage of California's property tax reduction measure Proposition 13 in 1978, political scientists have devoted greater attention to the willingness of policy advocates to abandon conventional representative institutions. Students of direct democracy have explored such topics as the role of money, interest groups, and voter competence in initiative campaigns; policy differences in initiative and non-initiative states; and implications of direct democracy elections for voter engagement, trust, and efficacy and their spillover effects on candidate campaigns.

Other researchers have noted that legislators' and other state officials' response to ballot initiatives can facilitate or complicate implementation and can affect the fate of proposals designed to reform the initiative process in the states (Bowler and Donovan 1999). The limited scholarship that examines legislative response typically uses formal models, case studies, and mail surveys to investigate lawmakers' attitudes or behavior in the most high-use initiative states, particularly California. The portrait of state legislators that emerges from some of these studies is often an unfavorable one. They may

KATHLEEN FERRAIOLO is an assistant professor of political science at James Madison University.

The American Review of Politics, Vol. 31, Spring, 2010: 41-64

(C)2010 The American Review of Politics 
report grudging acceptance of the ballot initiative process, but legislators see it as flawed, are eager to impose restrictions on it, and frequently alter the impact of winning initiatives to conform to their personal policy preferences.

In one of the most prominent works in this area, Stealing the Initiative: How State Government Responds to Direct Democracy, Elisabeth R. Gerber, Arthur Lupia, Mathew D. McCubbins, and D. Roderick Kiewiet (2000) design a formal model that predicts legislative compliance with successful initiatives and test that model using 11 case studies of California ballot measures (see also Gerber, Lupia, and McCubbins 2004). One of the main lessons of Stealing the Initiative is that, when conditions are right, legislators use their role in the implementation process in ways that undermine the preferences of the public and initiative proponents. In a series of studies, Bowler, Donovan, and their colleagues, meanwhile, find high levels of support for direct democracy among lawmakers and candidates in California, Oregon, and Washington (Bowler, Donovan, and Karp 2003; Bowler, Donovan, and Karp 2002; Bowler, Donovan, Neiman, and Peel 2001; Bowler and Donovan 1999). Thus, a paradox presents itself: legislators exhibit attitudinal support for direct democracy, but exploit opportunities to weaken initiative content post-ratification.

In this study, I develop a research design that combines the attitudinal and behavioral approaches to advance our understanding of legislative response to direct democracy. My study is the first to employ an original web survey to probe legislators' attitudes about direct democracy. This lowcost, innovative technological tool allowed me to survey all current legislators in the state of Oregon. I supplement the attitudinal portion of the article with two case studies of Oregon ballot measures to examine legislators' behavior in response to successful initiatives. ${ }^{1}$

My approach differs from the literature generally in another important way. I conduct my analysis not in California, the state that receives the lion's share of attention in the direct democracy literature, but in Oregon. Along with California, Washington, and Colorado, Oregon is a high-use initiative state, but it is one where direct democracy is not such an ingrained part of the political culture and where, critically, unlike in California, legislators are empowered to alter the content of winning initiatives. ${ }^{2}$ I propose that this environment may lead to differences in legislative response to direct democracy compared to Gerber et al.'s (2000) observations. To examine that possibility, I first investigate whether some of the conditions that Gerber et al. (2000) predict will influence initiative compliance in California are the same or different for Oregon lawmakers. I also examine the relative importance of those conditions as ranked by currently serving legislators and their actual behavior in response to successful initiatives. 
The evidence I examine leads to the conclusion that Oregon legislators are deferential toward the initiative process, are reluctant to tinker with the results of initiative elections, and when they do tinker are committed to preserving voters' intent while improving the language or workability of flawed bills. The findings provide a more complete portrayal of legislative response to initiatives, suggest that scholars should devote greater attention to attitudes and behavior in initiative states other than California, and should treat partial compliance with initiative outcomes as a continuum of options that may reflect recognition rather than rejection of voters' will or proponents' mandate.

\section{Overview of the Literature on Legislative Response to Direct Democracy}

The question of legislators' response to the threat or passage of initiatives and the relationship between the legislative process and the initiative process has received significant attention recently in the political science literature. While there are several works that reveal distinctive findings (including Gerber 1996a, Gerber 1996b, Burden 2005, and Smith 2001), I will focus on the Bowler, Donovan, and colleagues and Gerber et al. studies mentioned above, which speak most directly to the question of state government response to direct democracy.

In a series of articles, Bowler, Donovan, and Karp (BDK 2002), Bowler, Donovan, Neiman, and Peel (BDNP 2001), and Bowler and Donovan (BD 1999) use 1998 and 1999 data from mail surveys of legislators and legislative candidates in Canada, New Zealand, and three of the most frequent-use initiative states (California, Oregon, and Washington) to provide some of the first evidence of legislators' attitudes about direct democracy. BDK and BDNP discover that, overall, 77 percent of their United States respondents rated ballot initiatives as "good things," but a majority also believed that initiatives are too complicated for voters, that campaigns are misleading, and that initiatives produce bad laws. Oregon respondents were most likely to rate the initiative a good thing (80\%), compared to California (76\%) and Washington (75\%) respondents (BD 1999). Based on late1990s mail survey data, then, we may conclude that lawmakers in three of the most frequent-use states, while not ignorant of its flaws, report perhaps surprisingly high levels of support for direct democracy.

Another influential work that examines the relationship between state government and ballot measures is Stealing the Initiative: How State Government Responds to Direct Democracy. In this 2000 book, Gerber and her colleagues (GLMK) test a formal model against 11 case studies of successful California initiatives to evaluate the factors that influence whether winning 
initiatives shape public policy. Early in their work the authors assert that "we prove that under normal conditions, government actors' policy preferences displace initiative content - at least in part - as the ultimate determinant of a winning initiative's policy impact." The case studies, the authors go on to argue, "reinforce this finding by showing multiple instances where elected representatives who were against popular initiatives in California prevented their full implementation. Such actors literally 'steal' the initiatives" (2000, viii). Indeed, GLMK's case studies document several instances of halfhearted legislative compliance with winning initiatives or brazen disregard for the objectives of initiative supporters. In a separate contribution, Gerber, Lupia, and McCubbins (GLM 2004) conclude that "full compliance is impossible for a large class of initiatives" $(2004,45)$.

Given the absence of full compliance with initiative outcomes among California lawmakers, BDK's finding of strong support for direct democracy in that state is even more surprising. Behavioral and attitudinal data thus seem to lead to divergent findings. How can we explain legislators' support for direct democracy given their attempts to undermine, at least partially, initiative content? Were legislators systematically untruthful in responding to BDK's questionnaire? Is stealing the initiative a phenomenon unique to California? What is the content of legislators' attitudes and behavior elsewhere, and what factors affect their willingness to comply with winning initiatives? The remainder of the study considers these and other questions by gathering and examining additional attitudinal (via a web survey) and behavioral (via case studies) data.

\section{Modifying a Theory of Legislative Response}

GLM contend that variation exists in government actors' response to winning initiatives, ranging from complete compliance, to mild "reinterpretation," to utter indifference $(2004,44)$. GLM and GLMK identify factors that influence compliance among legislators and bureaucrats at the implementation, enforcement, and sanctioning stages of initiative politics. In this study, I focus on the role of legislative actors as implementation leaders responsible for enacting bills that explain and clarify how winning measures will be put into action.

GLM and GLMK's model of legislative response points to several factors likely to influence compliance. First, high technical (including the time and monetary costs of having legislative staff determine how to implement an initiative as well as the costs of establishing, administering, and monitoring mandated programs) and political (the difficulty of taking resources away from other programs to comply with an initiative and pressures from constituents, parties, or interest groups) costs discourage full compli- 
ance (GLM 2004, 50; GLMK 2000, 20). On the other hand, a high threat of sanctions from proponents, including possible lawsuits for noncompliance as well as withdrawing electoral or financial support from uncooperative elected officials when they run for re-election, can encourage cooperation with and enforcement of initiative outcomes. This is particularly true "when an initiative's means and ends are clear, when proponents have good information, and when proponents can mobilize the resources needed to carry out sanctions" (GLMK. 2000, 21). Finally, GLM posit that as the precision of an initiative's policy instructions decreases, the likelihood of full compliance goes to zero $(2004,58)$.

One of the objectives of this study is to test portions of GLMK's theory of legislative compliance in an environment outside California that is more typical of the political culture and institutional rules governing the direct democracy process in the other 22 initiative states. California legislators are prohibited from independently amending or repealing ballot measures (approved initiatives can only be altered by another initiative), an uncommon provision that forces lawmakers to (at least attempt to) implement initiatives to which they may object in principle. In addition, state law requires an additional popular vote to ratify legislative modifications to ballot measures, while in most other states, including Oregon, legislators can repeal or amend a statutory ballot measure by a simple majority vote. ${ }^{3}$ California's restrictive amendment process, along with its highly professionalized legislature and a political culture in which direct democracy and legislative government are perceived as adversarial (direct democracy is sometimes derisively referred to as the "fourth branch of government" in California), contrast with a political culture and institutional rules that appear to encourage greater legislative toleration of direct democracy outcomes in Oregon. By selecting Oregon, I have also controlled for one important factor that may influence compliance: frequency of use (California and Oregon are among the most high-use initiative states). In addition, I ask legislators to rank order the conditions under which they are more or less likely to support initiative outcomes or amendments. This approach allows me to identify which factors exert the strongest pull on decisions about initiative postelection politics. ${ }^{4}$

BD (1999) find that California legislators (36\%) are significantly less likely than their counterparts in Washington $(59 \%)$ and Oregon $(70 \%)$ to support legislative efforts to "fix flaws" in initiatives. Indeed, constrained by the prohibition on amending or repealing voter-approved measures, California lawmakers may have little choice but to steal the initiative when ballot measure content is objectionable to them. ${ }^{5}$ In contrast, legislators in even high-use states that permit modifying amendments do not need to steal the initiative in order to rework flawed measures; instead, they are 
empowered - and many voters and initiative supporters expect them-to streamline language, alter funding timetables, or institute other changes they believe are consistent with voters' intentions. Consistent with Bowler and Donovan's (2004) exhortation, this study asserts that direct democracy scholars should continue to examine legislative compliance with direct democracy in high-, moderate-, and even low-use states.

I also offer a reinterpretation of the notion of "partial compliance" with voter-ratified initiatives. GLMK consider compliance to be full when "government actors implement and enforce an initiative in the way its authors intended" $(2000,5)$. The model seems to assume that public support for a ballot measure indicates complete agreement with all of the goals and preferences of its proponents: when the conditions for full or partial compliance are not met, "someone, somewhere, will reinterpret or reject the voters' mandate" or "the legislation passed on Election Day" (GLMK 2000, 25 and GLM 2004, 59; emphasis added). In their conclusion, GLMK state that because government actors exercise some discretion over winning initiatives, "the policy impact of most initiatives reflects a compromise between what electoral majorities and government actors want" (2000, 110; emphasis added).

While I agree with GLM and GLMK that the conditions for full compliance are rarely met, I propose that the concept of full compliance itself is unhelpful. As the authors acknowledge, for a large class of initiatives, compliance not only fails to occur but is difficult to measure. "Some initiatives specify a policy goal without explicitly describing the means for achieving the goal," GLM note, while "others specify the steps a government must take but are vague about what end results are desired" (2004, 52). Proponents who sponsor an initiative that either already has broad public support or, on the other hand, one that is less popular, each have an incentive to minimize discussion of policy details in order to attract an electoral majority (GLM 2004, 58). The common problem of vague or ambiguous language about initiative means or ends complicates our ability to both measure and observe full compliance with initiative outcomes. More broadly, it is unclear why we should treat full compliance as a standard or expectation under direct democracy and any deviation from it a "reinterpretation" or "rejection" of proponents' or voters' will when in the legislative context, most enacted statutes do not persist unchanged in perpetuity but are refined and modified over time.

In short, I expect that partial compliance will be the standard legislative response to successful ballot measures and that this outcome is often consistent with voters' preferences. The evidence allows me to examine the conditions that make partial compliance more likely and to investigate the 
process of partial compliance in a state where legislative amendments to successful initiatives are more common and more expected. When lawmakers alter ballot propositions such that their literal interpretation as written is replaced with modifications to wording, timeline, funding, or other features that enhance the measure's feasibility while preserving its core objectives in ways that the voting public (and perhaps even initiative proponents) tolerate or support, partial compliance may in fact produce outcomes that fully satisfy both electoral majorities and government actors.

In summary, this research builds upon BDK/BDNP/BD's studies of attitudinal support for direct democracy by considering whether legislative behavior corresponds with survey responses. More importantly, it offers two primary modifications to GLMK/GLM's understanding of legislative response to direct democracy. First, it argues for the importance of studying legislative attitudes and behavior in environments where institutional rules and regulations on initiative amendments are less stringent. Second, the study proposes that rather than "stealing the initiative," legislative tampering with initiative content may reflect attempts to remedy the language, timeline, or funding of popular but flawed measures. Rather than use the concept of full compliance as a standard, scholars ought to seek to better understand the process and outcomes of partial compliance as a continuum of options that enables lawmakers to preserve rather than undermine the central objectives of voters and initiative proponents.

\section{Study Methodology}

What, then, is the content of legislators' views about the initiative process and what factors influence whether they will comply with the results of successful measures? My primary source of attitudinal data is web survey responses from Oregon lawmakers. During the summer and fall of 2007, I surveyed 90 Oregon lawmakers (60 House members and 30 senators) serving in the 2007 Regular Session using the WebSurveyor software program. A survey link was sent by e-mail to all Oregon legislators in May 2007. Various techniques including mailed letters, telephone calls, and five to six follow-up e-mail messages were used to increase the response rate. The survey had a final response rate of 27 percent. $^{6}$ While the number of survey responses is relatively low and the response rate somewhat lower than what is typically reported for public opinion surveys, mail surveys of state legislators and legislative candidates have achieved similar response rates ranging from 13 (Herrnson 2000) to 17 (Francia and Herrnson 2004) to 35 (Maestas 2003) or 36 (BDNP 2001) percent. Elected officials receive many survey and interview requests, and they may be less likely to respond to a 
questionnaire sent by a non-constituent and, indeed, a non-state resident. Given these and other constraints, including the demanding nature of session schedules, the response rate should be considered within an acceptable range.

Further, Table 1 documents that respondents were in some important ways representative of the population of Oregon legislators. Republicans and Democrats participated in the survey in similar numbers, and the average length of service of respondents was just under four and a half years (Oregon lawmakers are not subject to term limits). Party leaders completed the survey in higher numbers than rank-and-file members, perhaps not surprisingly since they are more likely to be familiar with the initiative process and to have formed opinions about it given their active leadership roles and longer tenure in office.

Table 1. Survey Respondents and State Legislative Body

\begin{tabular}{ll}
\hline Percent Republican (Actual / In Survey) & $44 \% / 44 \%$ \\
Percent Democratic (Actual / In Survey) & $54 \% / 56 \%{ }^{7}$ \\
Percent conservative & $35 \%$ \\
Percent liberal & $35 \%$ \\
Percent moderate & $29 \%$ \\
Average length of service in years & 4.44 \\
Percent who serve in a leadership role & $44 \%$
\end{tabular}

As a second key source of data, I conduct two case studies to explore whether Oregon legislators' behavior in response to successful initiatives is consistent with their attitudes. I selected the case studies based on a review of initiatives ratified since the mid-1990s, a period when Oregon witnessed an uptick in the use of the initiative process. Topics covered included marriage, term limits, the minimum wage, guns, education, tobacco settlement proceeds, and taxes. In selecting cases I sought out salient issues (otherwise, coverage of implementation decisions and actions would have been impossible to locate) that have appeared on multiple state ballots in recent years. Due to the relatively low passage rate for voter initiatives (which is in the $40 \%$ range) and the fact that not all successful initiatives require legislative involvement in the implementation process, the universe of potential topics was somewhat limited. For each issue I selected-land-use regulations and medical marijuana-I discuss the conditions surrounding the measure's passage, examine legislative decisions about whether or not to tinker with successful initiatives, and evaluate the content of implementing legislation. 


\section{Legislators' Views About the Initiative Process}

After consenting to participate in the web survey, the first question legislators were asked was the following: "Overall, do you think that statewide ballot propositions are a good thing for Oregon, a bad thing, or do you think they make no difference?" The question wording was identical to BD/BDK's in the articles discussed above in which the authors discovered both support for and concerns about direct democracy.

BD found in 1999 that 80 percent of legislators and candidates in Oregon reported that initiatives are "a good thing." I also found majority support among Oregon legislators: 56 percent of respondents approved of initiatives, 33 percent disapproved, and 11 percent either said initiatives made no difference or had no opinion. There may be several reasons why BD report more positive attitudes about direct democracy among Oregon legislators. The passage of time and an uptick in initiative use may have resulted in more dissatisfaction with direct democracy than the authors discovered in their late 1990s survey. In addition, while my survey included only currently serving officeholders, BD surveyed incumbent legislators as well as legislative candidates, whose relative inexperience with the initiative process may have led to more positive attitudes.

The bulk of the remaining survey questions then dealt with legislators' attitudes about tinkering with successful initiatives. GLM and GLMK identify several factors likely to influence legislative compliance with initiative outcomes in California, including technical and political costs, threat of sanctions, and precision of initiative's policy instructions. In the next section of the study, I use web survey data to test the applicability of GLMK's model in the state of Oregon. The evidence demonstrates that Oregon lawmakers tolerate direct democracy as a constructive, if imperfect, aspect of state government, and the results also deepen our understanding about the relative importance of the conditions under which lawmakers believe tinkering with voter-ratified measures is acceptable. In particular, I find that technical questions related to initiative language and political questions touching on public support loom especially large in lawmakers' decisions about the appropriateness of modifying voter-ratified measures.

Survey respondents were presented with a number of ways in which they might respond to a successful initiative, ranging from "full compliance," to "modifications with restrictions," to "full displacement." The results are presented in Table 2. Not surprisingly, respondents overwhelmingly disagree that legislators should ignore election results and displace initiative content. One-third of Oregon legislators agreed with full compliance, one-third neither agreed nor disagreed, and just over one-quarter disagreed with the notion that full compliance should result when legislators 
Table 2. Oregon Legislators' Views About Initiative Response

\begin{tabular}{|c|c|c|c|}
\hline & Agree & Neutral & Disagree \\
\hline $\begin{array}{l}\text { FULL COMPLIANCE } \\
\text { "Legislators should fully comply with } \\
\text { the language and content of the initiative, } \\
\text { even if they think it is bad for their } \\
\text { constituents." }\end{array}$ & $\begin{array}{c}33 \% \\
6\end{array}$ & $\begin{array}{c}33 \% \\
6\end{array}$ & $\begin{array}{c}28 \%{ }^{8} \\
5\end{array}$ \\
\hline $\begin{array}{l}\text { MODIFICATIONS } \\
\text { WITH RESTRICTIONS } \\
\text { It is appropriate for legislators to attempt } \\
\text { ro tighten, clarify, or improve parts of } \\
\text { the initiative such as language, details, } \\
\text { or funding, so long as voters' intent } \\
\text { is preserved." }\end{array}$ & $\begin{array}{c}100 \% \\
18\end{array}$ & 0 & 0 \\
\hline $\begin{array}{l}\text { FULL DISPLACEMENT } \\
\text { "Legislators should feel free to displace } \\
\text { the initiative's content and try to move } \\
\text { policy outcomes closer to ones they prefer." }\end{array}$ & $\begin{array}{c}5.6 \% \\
1\end{array}$ & $\begin{array}{c}5.6 \% \\
1\end{array}$ & $\begin{array}{l}89 \% \\
16\end{array}$ \\
\hline
\end{tabular}

believe initiative content would be detrimental to their constituents. All respondents agreed that legislators should be permitted to alter initiative "language, details, or funding, so long as voters' intent is preserved," and nearly 89 percent of respondents reported having voted to amend an initiative. Thus, "full displacement" is rejected, "full compliance" receives support from one-third of legislators, and "modifications with restrictions" receives unanimous support. ${ }^{9}$ While some social desirability bias may have affected legislators' responses to these questions, case study evidence presented in the next section demonstrates that their behavior corresponds closely with their attitudes.

The next several survey questions asked legislators to evaluate whether they would be more or less likely to approve amendments to an initiative under several hypothetical scenarios. The results discussed below are presented in Table 3.

GLM and GLMK consider which variables affect compliance with winning initiatives, with compliance defined as "actors' decisions to implement or enforce initiatives" (GLMK 2000, 5), or more specifically, "the extent to which an implementation or enforcement action matches the policy described in the initiative" (GLM 2004, 45), while I ask legislators to identify conditions that affect their support for modifying amendments. I believe 
Table 3. Support for Initiative Amendments

\begin{tabular}{|c|c|c|c|}
\hline $\begin{array}{l}\text { Would you be more or less likely } \\
\text { to approve amendments to an initiative } \\
\text { under the following conditions... }\end{array}$ & $\begin{array}{l}\text { More } \\
\text { Likely }\end{array}$ & $\begin{array}{l}\text { Neither } \\
\text { More nor } \\
\text { Less Likely }\end{array}$ & $\begin{array}{c}\text { Less } \\
\text { Likely }\end{array}$ \\
\hline $\begin{array}{l}\text { LANGUAGE } \\
\text { When initiative language is clear }\end{array}$ & $\begin{array}{l}6 \% \\
1\end{array}$ & $0 \%$ & $\begin{array}{l}94 \% \\
17\end{array}$ \\
\hline $\begin{array}{l}\text { MONETARY COSTS } \\
\text { When monetary costs of implementation } \\
\text { are prohibitively high }\end{array}$ & $\begin{array}{c}44 \% \\
8\end{array}$ & $\begin{array}{l}56 \% \\
10\end{array}$ & $0 \%$ \\
\hline $\begin{array}{l}\text { PUBLIC SUPPORT } \\
\text { When there is strong public support } \\
\text { for the measure }\end{array}$ & $\begin{array}{l}5 \% \\
1\end{array}$ & $\begin{array}{c}17 \% \\
3\end{array}$ & $\begin{array}{l}78 \% \\
14\end{array}$ \\
\hline $\begin{array}{l}\text { TIMELINE } \\
\text { When the timeline for meeting the } \\
\text { initiative's prescriptions is unrealistic }\end{array}$ & $\begin{array}{l}70 \% \\
12\end{array}$ & $\begin{array}{l}6 \% \\
1\end{array}$ & $\begin{array}{c}24 \% \\
4\end{array}$ \\
\hline $\begin{array}{l}\text { POLITICAL COSTS } \\
\text { When you perceive high political } \\
\text { costs for noncompliance }\end{array}$ & $\begin{array}{c}12 \% \\
2\end{array}$ & $\begin{array}{c}41 \% \\
7\end{array}$ & $\begin{array}{c}47 \% \\
8\end{array}$ \\
\hline
\end{tabular}

this difference in the dependent variable still allows for a test of the authors' theory of legislative compliance and is appropriate given Oregon lawmakers' unanimous support for the "modifications with restrictions" position and given my objective of uncovering the factors that make the selection of that position in particular cases more or less likely. ${ }^{10}$

For an overwhelming majority of legislators, the most important factor in supporting or opposing amendments was initiative language. Nearly 95 percent of Oregon lawmakers reported that "specific, clear, and unambiguous" initiative language makes them less likely to support amendments. Legislators' opposition to tinkering under this condition could be a result of either their commitment to popular rule or their fear that attempts to overturn unambiguously worded measures would be politically costly. In open-ended comments, one lawmaker provided an example: "We had a measure dealing with property taxes that was written too poorly to be implemented. We referred it back out in a workable form." Another legislator recalled that "the language of a [particular] initiative was vague and unclear, with a high fiscal and policy cost. It was clear that the intent of the measure was different than the resulting outcome and the measure required clarification to preserve this original intent." A separate survey question revealed that a majority of 
respondents - nearly 60 percent-identified initiative language as the most important factor in the decision of whether or not to support amendments. Survey evidence also showed that another initiative-specific factor-the timeline a measure proposes - affects legislative attitudes; 71 percent of respondents indicate that an unworkable timeline for meeting an initiative's prescriptions would make them more likely to support changes.

In their model of initiative compliance, GLMK focus primarily on "features of the political" and "economic environment" $(2000,109)$ that affect compliance, including the preferences of political actors, the resources of an initiative's proponents, and a measure's fiscal impact on the state budget. Elsewhere, GLM (2004) propose that the precision of a measure's policy instructions will have a positive relationship with full compliance. The survey results from Oregon presented here indicate that specificity and clarity of ballot proposition wording is by far the most important factor that shapes legislative response.

Other survey evidence demonstrates that political factors are also an important consideration for lawmakers. Seventy-eight percent reported that strong public support makes them less likely to support amendments, and public support was cited as the second most important factor (after initiative language) in legislators' decisions about voting on amendments. Similarly, when legislators perceive high political costs for noncompliance (such as "when strong majorities of your constituents support the initiative"), a plurality of 47 percent are less likely to favor changes. The Oregon survey results reinforce GLMK's (2000) finding that political costs affect legislative response to direct democracy, but such considerations are clearly secondary to initiative language.

In GLMK's (2000) theory, technical costs involving time and money that must be dedicated to implementing initiative results have a significant impact on legislative compliance. I find that concerns about monetary costs did not generate the same reaction among Oregon legislators as did the issues of public support, language, and timeline. Even when monetary costs are "prohibitively high," only 44 percent of respondents indicate that they would be likely to support changes to voter-ratified measures; a majority of lawmakers indicate that monetary costs would have no effect.

Taken together, the results suggest that legislators are reluctant to tinker with the outcomes of successful initiatives and that the conditions under which they will tinker depend not on features of the economic environment but primarily on the initiative itself and proposed amendments as well as, to a lesser extent, political considerations. Clear language, realistic timelines, and strong public support generate significant reservations about modifications. While high monetary and political costs also discourage legislators from supporting changes to voter-ratified bills, the effect of these factors is smaller. 


\section{Case Studies of Successful Initiatives in Oregon}

The survey evidence advances our understanding of legislative attitudes about direct democracy by providing a fuller picture of the conditions under which legislators support initiative amendments. One might argue, however, that it is unreasonable to expect lawmakers to report truthfully on their attitudes and behavior, particularly when information they reveal might cast them in a negative light. What legislator would confess, after all, that he or she believes the legislature should be empowered to displace ballot proposition outcomes or that the initiative process should be forbidden?

The next section of the study will draw primarily on journalistic accounts to consider legislative and, to a lesser extent, gubernatorial responses to two ballot measures and will evaluate whether legislators' behavior is consistent with their attitudes. Over the last decade, Oregon voters have considered initiatives on topics including affirmative action, gambling, and school vouchers. The case studies trace the passage and implementation of measures dealing with land use and medical marijuana. The U.S. Supreme Court's 2005 Kelo v. City of New London decision prompted an explosion of land use reform legislation and ballot measures, and since 1996 voters in 12 states, most by initiative, have ratified medical marijuana laws, often overwhelmingly.

\section{Land Use in Oregon}

In November 2004, Oregon voters approved Measure 37, which granted land-use waivers to owners who had purchased their property before regulations were enacted (thereby allowing development to take place) or required counties to compensate owners for value lost as a result of regulations. The measure passed by a margin of 61 to 39 percent and received majority support in all but one county. Turnout was strong and there was little ballot drop-off: 71 percent of eligible voters and 86 percent of registered voters cast a ballot in 2004 general election, and 67 percent of eligible voters and 81 percent of registered voters cast a ballot on Measure 37 (“Statistical Summary" 2004).

Measure 37 stipulated that local and state governments would be required to process all claims within 180 days, and Oregon estimated the cost of administering claims at $\$ 18$ to $\$ 44$ million for the state and $\$ 46$ to $\$ 300$ million for local governments (Barnard 2004). The 2004 initiative was a statutory measure backed by the same groups that supported a similar constitutional amendment in 2000, which was also ratified by voters but never took effect after a successful court challenge. Measure 37 was widely viewed as a backlash against the state's rigid land-use rules, which were in 
large part a result of a pioneering law passed by the Oregon Legislature in 1973 that empowered local, county, and state governments to impose strict regulations designed to curb urban sprawl, preserve farmland, and confine new housing to already developed areas.

Beginning weeks after its passage, the challenges of putting Measure 37 into effect became apparent. City and county officials lobbied for clarity about how to implement the new law as their planners lacked a standard system with which to evaluate claims that poured in. Environmentalists and other opponents pointed to proposed casinos and farmland subdivisions to argue that the law should be blunted to save the state's land-use laws, which they claimed were originally designed to protect landscape, water supply, and quality of life. The measure pitted neighbors against one another as property owners sought to subdivide and develop their land and neighbors voiced concerns about adequate water, increased traffic, and urban sprawl.

Despite such complaints, legislators were keenly aware that nearly twothirds of state voters approved the initiative in a high-turnout election. In an early 2005 legislative committee meeting, one Democratic state senator who opposed Measure 37 likened it to a "wake-up call for public frustration"; a Republican senator who supported it mused that "Maybe we shouldn't change Measure 37. Maybe 61 percent of Oregonians spoke loud and clear." Democratic Senator Charlie Ringo remarked in response that "I don't think 61 percent of Oregonians read Measure 37 and intended every comma and every word to become law.... I think they threw the whole system up in the air, and our job is to catch it as it comes back down" (Oppenheimer 2005). The spokesperson for Democratic Governor Ted Kulongoski, who opposed the initiative, expressed similar sentiments, noting that the governor "dislikes Measure 37 but thinks it is state government's job to make it work" ("Kulongoski compromises" 2005). Similar to the web survey results, in their public comments on Measure 37 state officials suggested that it was their responsibility to fix a flawed bill in a way that preserved voters' core intent.

With court action ongoing (a circuit court judge struck down the initiative in 2005, but the state Supreme Court reinstated it in 2006), in late 2005 legislators passed a bill establishing a 10-member Oregon Task Force on Land Use Planning (colloquially known as the "Big Look" committee) to research and evaluate the effectiveness of Oregon's land-use planning program in handling current and future needs and to make recommendations to the Legislature in 2007 and 2009. The task force was charged with undertaking a broad, comprehensive effort to gather opinions and ideas (which it did through an online survey of Oregonians) and forge a consensus around a long-range solution to statewide land-use planning. In 2006, the group identified six key issues for further analysis and evaluation, and it presented its preliminary findings in July 2007. 
By early 2007, the Legislature and governor agreed that Measure 37's unintended consequences and the burdens it imposed on local governments demanded that they take action. Since the measure had gone into effect in early December 2004, more than 7,500 claims on 750,000 acres had been filed statewide, requesting compensation that totaled nearly $\$ 10$ billion. A 10-member joint House-Senate Land Use Fairness Committee was formed to fast-track legislation designed to address problems with the state's land-use planning system. Committee co-chair Democratic senator Floyd Prozanski said in January 2007 that "I feel very comfortable and very confident that ... those who are trying to do land speculation, build subdivisions and stuff, that was not the intent of voters" ("Kulongoski prods Oregon Legislature" 2007). The committee spent several months holding hearings and considering testimony from hundreds of Oregonians as members evaluated how Measure 37 implementation was affecting the state. Meanwhile, lawmakers debated legislation that would remedy the defects of Measure 37 while preserving voters' goal of rolling back some of the state's rigid land-use regulations. Research, opinion surveys, and communication with citizens "clearly show that Oregonians want to retain our land use system; they just want to tweak it to make it more fair," Prozanski claimed (Bjornstad 2007). Polling showed that a majority of state residents agreed that the initiative needed to be fixed: in a May 2007 survey, 56 percent of Oregonians said that they at least leaned toward voting yes on a rewrite of Measure 37; about 28 percent at least leaned against it (Oppenheimer 2007).

In the closing days of the legislative session in June 2007, after lawmakers failed to reach a compromise on a legislative fix to Measure 37, they crafted a ballot measure to put before voters in a 2007 special election and framed it as a way to restore landowners' rights while protecting farms and forests. The measure passed the House and Senate along party lines, with Democrats supporting it and Republicans opposed. In November 2007, voters ratified Measure 49 by 62 to 38 percent - a margin of victory almost identical to the one for Measure 37 in 2004. Voter turnout for the 2007 special election was solid but, as can be expected, it was lower than turnout in the 2004 general election: 42 percent of eligible voters and 60 percent of registered voters cast a vote on Measure 49 ("Statistical Summary" 2007).

The 2007 initiative gave priority to rural landowners who applied to build as many as three homes; allowed for the possibility of four to 10 homes if an appraisal showed land-use rules sufficiently devalued property; and banned larger subdivisions and commercial developments (Oppenheimer 2007). These limitations were retroactive: they applied to property owners who had already been granted waivers that approved more than the allowed home sites. Measure 49 also set forth information applicants must furnish in the waiver application (making procedures uniform statewide 
rather than varied by jurisdiction, as was the case under Measure 37); provided more guidance in determining what constituted "just compensation" for landowners; and allowed property rights and development authorizations to be transferred to new owners (Hillier 2007; Mortenson 2007). In addition, after the passage of Measure 49, the governor and many legislators issued calls to reconvene the Big Look task force, and in February 2008 the Legislature restored its funding.

Measure 37 was widely viewed as a reaction against some of Oregon's longstanding, rigid land-use regulations. But - as is the case with many ballot measures - the initiative was crudely written and went too far, critics noted, "devolving land-use and open-space decisions to their least-regulated environment" (Schuck 2007). Consistent with the survey results, case study evidence demonstrates that legislators were sensitive to Measure 37's widespread support and proceeded cautiously in considering modifications. As unintended consequences became apparent and calls for a legislative fix intensified, lawmakers responded by gathering constituent input and crafted a compromise solution that they believed preserved voters' intent while addressing the initiative's flaws. Aware too that Measure 37 needed to be revised, voters supported that compromise by nearly the same margin by which they had approved the 2004 initiative.

\section{Medical Marijuana in Oregon}

Beginning with California's Proposition 215 in 1996, voters and legislatures in a total of 12 states have ratified measures that permit the use of medical marijuana. Oregon voters supported that state's medical marijuana initiative, Measure 67, by a margin of 55 to 45 percent in 1998. The turnout level for the medical marijuana measure $(57 \%$ of registered voters) was comparable to that of Measure 49 and typical for an off-year election ("Official Voter Participation Statistics" 1998). Measure 49 allowed Oregonians who had serious illnesses, including cancer, AIDS, glaucoma, and multiple sclerosis, to legally grow and use marijuana. Sick people whose physicians recommend marijuana would be able to register with the Health Division, which would issue identification cards exempting them from most state anti-marijuana laws. The Oregon Medical Marijuana Program allowed patients whose physicians signed off on their serious illness to grow limited amounts of marijuana or designate a caregiver to grow it for them.

As is the case with many ballot initiatives, in the years following Measure 67's passage, a number of unintended consequences became apparent. Medical marijuana supporters in the late 1990s argued that only a handful of seriously ill patients - perhaps 500 at most — would ever need to take advantage of the new law. In 2008, nearly 16,000 Oregonians held patient cards 
entitling them to use marijuana, another 8,000 held caregiver cards allowing them to possess it, and 4,000 held permits to grow the plant ("Don't Make a Bad Marijuana Law Worse" 2008). Critics contended that abuses of the law's permissiveness had brought about a spike in illegal possession and use of the drug; one commentary noted that "the increased utilization and expansion of the law has created a collision between cardholders and employers that was not originally contemplated when the law passed" (Salsgiver 2008).

Employers have been among the most vocal critics of Oregon's medical marijuana law. Employer groups have repeatedly turned to the Legislature to clarify the law, and legislators have not been unmoved by their insistence (Salsgiver 2008). The question of whether employers must accommodate medical marijuana cardholders has been litigated in state courts and debated in the Legislature. Several versions of a bill that would make it easier for employers to enforce their drug-free workplace policies (including against employees with valid medical marijuana cards who consume the drug off-site) have stalled (Tucker 2008).

Despite multiple attempts, the Oregon Legislature has thus far failed to enact legislation that would satisfy employers and medical marijuana cardholders alike. However, lawmakers have hardly been complacent in their response to Measure 67; they have enacted other proposals to address ambiguities in the meaning and implementation of the law. For example, in July 1999 the Legislature approved a bill that amended Measure 67 to include several clarifications, including the situations in which a person under 18 years of age may receive medical marijuana; that a person may not possess marijuana for medical purposes in a correctional facility; and that patients or their caregivers are permitted to grow medical marijuana in only one place (1999 Summary of Major Legislation). The measure passed overwhelmingly in the House (by a vote of 49-8) and in the Senate (by a vote of 27-3). In 2005 , another legislative measure, which was unanimously approved by the Senate and by a nearly three-to-one margin in the House, increased the amount of dried marijuana, plants, and seedlings registered cardholders could possess. In exchange for increased possession limits, the Legislature enacted a provision backed by police that patients and caregivers could no longer argue in court that having more than the specified amounts was a medical necessity and therefore permissible. The 2005 legislation also allowed caregivers to supply medical marijuana for up to four registered cardholders per year (the original law specified no such limits), created an 11-member Advisory Committee on Medical Marijuana in the Department of Human Services that would review and govern the program's administrative rules, and required the Department of Human Services to develop a 24- 
hour system for law enforcement to confirm that a person's use or possession is legal.

The 2005 measure was supported by groups as diverse as the Oregon Association of Chiefs of Police and Oregon NORML (National Organization for the Reform of Marijuana Laws). According to Kevin Campbell, executive director of the police chiefs group, lack of clarity in the existing law meant that law enforcement officers sometimes "can get in situations where they're not sure how to proceed. ... The reason we like the bill is that we think it clears up some of the ambiguity. It gives officers more solid ground to stand on" ("Senate signs off" 2005). State Senator Bill Morrisette, one of the legislation's co-sponsors, claimed that it aimed to put the state's medical marijuana program " "on more solid footing' by making it easier for police to interpret the law and harder for criminals to exploit it" (Cain 2005). The 2005 measure "provides the clear, bright lines that law enforcement needs to enforce the bill fairly, without infringement on the rights of those who legitimately use the product," according to Morrisette ("Senate signs off" 2005). "It protects these patients," Morrisette said, "and plugs some of the loopholes law enforcement people were worried about" (Cain 2005).

Since the passage of Measure 67 in 1998, Oregon legislators have introduced, considered, and debated several pieces of legislation designed to revise the initiative's language and smooth the implementation process. While legislators certainly have not been unanimously supportive, they have engaged in largely consensual and successful efforts to balance the competing demands of law enforcement, employer, and patient groups. Lawmakers have been preoccupied primarily with managing the unintended consequences of a popular ballot initiative, closing loopholes, and clarifying ambiguities in order to streamline the implementation of Measure 67 and ensure that voters' core intent - permitting the use of medical marijuana by seriously ill patients - is preserved.

What do legislators' responses to land use and medical marijuana initiatives in Oregon tell us about the politics of partial compliance? Consistent with survey findings, the case studies document that lawmakers' efforts to amend Measures 37 and 67 were driven by a desire to clarify ambiguities in wording that resulted in implementation challenges. The initiative amendment process allowed Oregon lawmakers to evaluate and respond to the long-term implications and effects of ballot measures, correct the myopic tendencies of state voters, and craft modifications to remedy flaws that became apparent over time, while at the same time striving to preserve voters' original objectives.

In sum, the case study evidence documents Oregon legislators' efforts to modify voter-approved measures in ways that preserve or clarify voters' preferences. Legislature-sponsored revisions to Measure 37 were more 
popular than the original proposal, and lawmakers developed bills that successfully balanced the demands of various groups interested in medical marijuana implementation. In both instances, legislators took steps to manage unintended consequences while using caution to preserve the messages they believed voters intended to send. In addition, for both initiatives lawmakers sent strong signals through subsequent legislative activityincluding the creation of the "Big Look" committee and the Advisory Committee on Medical Marijuana - that they took voters' concerns seriously and supported efforts to comply with initiative outcomes.

While concerns about generalizability might arise from a study that examines two issues in one state, for the reasons discussed earlier I believe that the results presented here have implications beyond land-use and medical marijuana and beyond the state of Oregon. The two topics I consider involve timely, high-profile issues that have appeared on numerous state ballots in recent years. Measure 37 and Measure 67 are also similar to many, if not most, other initiatives that provoke a legislative response in that challenges related to wording, timeline, and funding complicated implementation and led to unintended consequences. And while my analysis is limited to legislators' response to the initiative process in one state, it is not dissimilar from the bulk of the literature in the field that examines only California legislators and California initiatives. As discussed earlier, Oregon is more similar to other high- and moderate-use initiative states than California in that it imposes fewer restrictions on initiative modifications and amendments. Consequently, Oregon legislators' attitudes about and responses to ballot measures are arguably more applicable to other states than findings from California.

\section{Conclusion}

Legislators have a great deal of influence over the design, administration, and implementation of direct democracy institutions and policies in the states, and scholars must continue to investigate how lawmakers view, approach, and respond to the initiative process. That extreme proposals are more likely to appear as initiatives than moderate proposals (Gerber 1996b, 1999) suggests that state legislatures can play a powerful and meaningful role in modifying and moderating the content of voter-ratified measures. Survey and case study evidence indicate that lawmakers do not view the initiative exclusively as a "threat to the power and functions of the legislature" (BDNP 2001), but instead as a constructive, if flawed, component of state government whose outcomes should be treated with deference. ${ }^{11} \mathrm{My}$ approach has allowed me to hold frequency of use constant and investigate whether variation in a state's direct democracy environment and institutional 
rules produce different attitudes about compliance with initiative outcomes and toleration of amendments.

The results indicate that California legislators' response to successful initiatives may differ substantially from what we can expect from their counterparts in other states. While the California initiative amendment process is both more onerous and less likely to succeed, Oregon lawmakers do not need to steal the initiative in order for their modifications to be enacted. The findings suggest that the initiative-specific factor of a measure's wording or language is the most important determinant of legislative response to ballot measures. Public support and political considerations are cited as a secondary consideration in survey results, but the case studies document little hesitation to modify winning initiatives even in the face of strong public support. Contrary to some of GLMK and GLM's results, survey and case study evidence demonstrate that issues involving a measure's timeline and, particularly, monetary or fiscal costs are relatively unimportant.

More broadly, the results suggest that legislators are not eager to amend successful initiatives but say they do so reluctantly and only under certain conditions. Through their involvement in post-election politics, legislators' aim is less to obstruct the implementation process than to streamline it, clarifying and fine-tuning flawed or ambiguously worded measures and honoring voters' intent in ways they feel are workable and responsible. In short, while full compliance - the literal interpretation of approved ballot measures as written - may indeed be uncommon, the absence of unmodified implementation does not necessarily mean that the voters' will and election outcomes are being ignored or subverted. Legislators can and do engage in partial compliance with initiative outcomes in ways that recognize and uphold the core ideals of proponents and voters.

While this study has examined popular legislative modifications to two Oregon initiatives that were also popular at the ballot box, future research on the question of partial compliance should seek out and investigate situations in which legislative intervention occurs despite public opposition. Will legislators demonstrate as much deference to the initiative process when public support for modifications is minimal? The evidence presented here suggests that the public displays a surprisingly high threshold of tolerance for legislative amendments when both the public and lawmakers determine that initiative funding, timeline, or potential implications will complicate implementation (yet another recent example is 2008's Measure 57 mandating increased prison sentences for certain types of crimes; despite passing by a margin of 61 to 39 percent, survey data indicate that a majority of Oregonians support delaying or modifying implementation of the measure's most costly parts) (Sheketoff 2009). While in some cases (when initiative language is clear and unambiguous) legislative modifications are unnecessary 
and others (such as the ones discussed here) public support for such modifications is strong, it is possible that there may be still other instances when states legislatures have acted to amend ballot measures despite public resistance.

In addition, future scholarship on the question of when and under what conditions state government actors interfere with the initiative process should examine that question in a variety of high-, moderate-, and perhaps low-use initiative states. It is possible that lawmakers' compliance with initiative policy content varies based on a state's frequency of initiative use. For example, legislators in moderate- and low-use states may be less hostile to generally less ambitious measures that they encounter with less frequency compared to their counterparts in high-use states where initiatives are more often perceived as a nuisance to state government actors. In states where the initiative process is invoked rarely, the results of ballot measure elections may be treated with even greater deference and caution, and legislative attempts at tampering with initiative content may be aimed largely or primarily at improving policy content rather than subverting voters' will. Future research should continue to explore the possible connections between frequency of initiative use and legislative compliance with voter-ratified measures.

This study demonstrates that legislators' behavior in response to successful initiatives is consistent with their attitudes, and that Oregon legislators' positive views about direct democracy are not mere words. In their attitudes and behavior alike, most legislators demonstrate a preference for an implementation role that changes initiative content as little as possible, while ensuring the clarity and feasibility of measures that may have been written by political novices or single-issue groups. Future research should continue to rely on interview, survey, and case study data to evaluate legislative behavior in response to ballot measures in other high- and moderate-use initiative states.

\section{NOTES}

${ }^{1}$ For the sake of simplicity and to avoid overuse of the term "citizens' initiative," I use the terms "direct democracy," "ballot propositions," and "initiatives" interchangeably in this manuscript. When I use any of these terms I am referring to the citizen's initiative process whereby the drafting and circulation of ballot measures originates with voters (and not state legislators).

${ }^{2}$ In order to identify states as low-, moderate-, or high-use, I rely upon the Initiative and Referendum Institute's historical data on statewide initiative use from 1905-2005 (Initiative and Referendum Institute, "Initiative Use"; see also Smith and Tolbert 2007). 
${ }^{3}$ In limited circumstances, Oregon law requires a supermajority (three-fifths or twothirds) legislative vote to amend or repeal a statutory initiative, primarily in the case of revenue measures.

${ }^{4}$ While GLMK gathered information about factors affecting compliance from state and campaign records, I believe that asking legislators for their views about the technical, political, and other costs of initiative compliance is an equally valid and reliable way of tapping into the same construct (I address concerns related to survey response bias below).

${ }^{5}$ In addition, Smith (2008) finds that legislators in high-use states are more likely to introduce and enact legislation designed to restrict the use of direct democracy.

${ }^{6}$ Data presented in Table 2 and Table 3 below reflect a response rate of $20 \%$, as a number of survey respondents skipped one or all of the questions that correspond with these results.

${ }^{7}$ Percentages do not total 100 because one representative is an Independent.

${ }^{8}$ One respondent answered "Don't know."

${ }^{9}$ That some lawmakers support both full compliance and modifications with restrictions should not be seen as contradictory. It is easy to imagine circumstances in which legislators would believe that one option or the other is the preferable response to a successful initiative (perhaps full compliance when a measure is seen as clearly worded and self-executing, and modifications with restrictions when implementation threatens to introduce unintended consequences or supermajority requirements necessary for amending a revenue measure can be overcome).

${ }^{10} \mathrm{We}$ can expect both variables to accurately capture legislators' attitudes, but consistency in the results would be observed simply as the relationships moving in opposite directions. For example, if GLM/GLMK find that precision in policy instructions increases the likelihood of full compliance, I would find that such precision decreases support for initiative amendments.

${ }^{11}$ While this study has demonstrated that legislators' post-ratification behavior is often centered around clarifying, fine-tuning, or fixing flawed initiatives, it is also true that there are instances when lawmakers use the initiative process as a way to avoid responsibility for making difficult or controversial policy decisions.

\section{REFERENCES}

1999 Summary of Major Legislation. Oregon Legislature. Policy, Research, and Committee Services. http://www.leg.state.or.us/comm/commsrvs/ssml99.pdf (July 17, 2008).

Abbe, Owen J., and Paul S. Herrnson. 2004. Campaign Professionalism in State Legislative Elections. State Politics and Policy Quarterly 3:223-245.

Barnard, Jeff. 2004. Measure 37 Would Change Land Use Regulation in Oregon. Associated Press State \& Local Wire, November 2.

Bowler, Shaun, and Todd Donovan. 2004. Measuring the Effect of Direct Democracy on State Policy: Not All Initiatives are Created Equal. State Politics and Policy Quarterly 43:345-363.

Bowler, Shaun, and Todd Donovan. 1999. Elite Attitudes about Direct Democracy. Paper presented at the Western Political Science Association Annual Meeting. 
Bowler, Shaun, Todd Donovan, and Jeffrey Karp. 2003. Popular Attitudes toward Direct Democracy. Paper presented at the American Political Science Association Annual Meeting.

Bowler, Shaun, Todd Donovan, and Jeffrey A. Karp. 2002. When Might Institutions Change? Elite Support for Direct Democracy in Three Nations. Political Research Quarterly 55:731-754.

Bowler, Shaun, Todd Donovan, Max Neiman, and Johnny Peel. 2001. Institutional Threat and Partisan Outcomes: Legislative Candidates' Attitudes toward Direct Democracy. State Politics and Policy Quarterly 1:364-379.

Bjornstad, Randi. 2007. Measure 37: Small Claims, Big Break. The Register Guard, February 6.

Burden, Barry. 2005. Institutions and Policy Representation in the States. State Politics and Policy Quarterly 5:373-393.

Cain, Brad. 2005. Medical Marijuana Changes Among New Jan. 1 Laws. Associated Press State \& Local Wire, December 26.

Colburn, Don. 2001. State Adds Rule for Medical Marijuana. The Oregonian, August 11, p. E1.

Donovan, Todd. Classification of States in Terms of Formal Rules for Initiative Use. http://www.ac.wwu.edu/ donovan/inituse.pdf (June 6, 2008).

Don't Make a Bad Marijuana Law Worse. 2008. Editorial. The Oregonian, February 2.

Francia, Peter L., and Paul S. Herrnson. 2004. The Synergistic Effect of Campaign Effort and Election Reform on Voter Turnout in State Legislative Elections. State Politics \& Policy Quarterly 4:74-93.

Gerber, Elisabeth. 1996a. Legislative Response to the Threat of Popular Initiatives. American Journal of Political Science 40:99-128.

Gerber, Elisabeth R. 1996b. Legislatures, Initiatives, and Representation: The Effects of State Legislative Institutions on Policy. Political Research Quarterly 49:263-286.

Gerber, Elisabeth R. 1999. The Populist Paradox: Interest Group Influence and the Promise of Direct Legislation. Princeton, NJ: Princeton University Press.

Gerber, Elisabeth R., Arthur Lupia, and Mathew D. McCubbins. 2004. When Does Government Limit the Impact of Voter Initiatives? The Politics of Implementation and Enforcement. The Journal of Politics 66:43-68.

Gerber, Elisabeth R., Arthur Lupia, Matthew D. McCubbins, and D. Roderick Kiewiet. 2000. Stealing the Initiative: How State Government Responds to Direct Democracy. Upper Saddle River, NJ: Prentice Hall.

Herrnson, Paul S. 2000. Congressional Elections: Campaigning at Home and in Washington. Washington, DC: CQ Press.

Hillier, Thomas S. 2007. Commentary: Oregon Voters Revisit Measure 37. Daily Journal of Commerce, July 26.

Initiative and Referendum Institute. Initiative Use. http://www.iandrinstitute.org/IRI\%20 Initiative\%20Use.pdf (June 5, 2008).

Kulongoski Compromises on Measure 37. 2005. Associated Press State \& Local Wire, July 30 .

Kulongoski Prods Oregon Legislature to Act on Measure 37. 2007. Associated Press State \& Local Wire, January 20.

Maestas, Cherie. 2003. The Incentive to Listen: Progressive Ambition, Resources, and Opinion Monitoring Among State Legislators. Journal of Politics 65:439-456.

Mortenson, Eric. 2007. Measure 49 Rouses Emotions of Voters. The Oregonian, October 24 . 
Official Voter Participation Statistics: November 3, 1998 General Election. Oregon Secretary of State, Elections Division. http://www.sos.state.or.us/elections/nov398/ other.info/totreg.htm (April 1, 2010).

Oppenheimer, Laura. 2007. Land-Use Measure Crafted with Care. The Oregonian, June 26.

Oppenheimer, Laura. 2005. Measure 37 has Lawmakers in a Bind. The Sunday Oregonian, February 13.

Salsgiver, Mike. 2008. Commentary: Medical Marijuana Saga Rolls on in Oregon. Daily Journal of Commerce, March 6.

Schuck, Eric. 2007. In My Opinion, Measure 49, Yes: Putting an End to Land Use by Lottery. The Oregonian, October 17.

Senate Signs off on Clarifications to Medical Marijuana Program. 2005. Associated Press State \& Local Wire, July 22.

Sheketoff, Charles. 2009. Let's Suspend Measure 57; Facing Severe Budget Cuts, Oregon Should Delay Funding the Crime Measure. The Sunday Oregonian, May 24.

Smith, Daniel A. 2008. The Legislative Regulation of the Initiative. Paper presented at the 7th Annual State Politics and Policy Conference, May 30-31.

Smith, Daniel A. 2001. Homeward Bound?: Micro-Level Legislative Responsiveness to Ballot Initiatives. State Politics and Policy Quarterly 1:50-61.

Smith, Daniel A., and Caroline Tolbert. 2007. The Instrumental and Educative Effects of Ballot Measures: Research on Direct Democracy in the American States. State Politics and Policy Quarterly 7:416-445.

Statistical Summary, 2007. November Special Election. Oregon Secretary of State Elections Division. http://www.sos.state.or.us/elections/nov62007/nov07stats.pdf (April 8, 2010).

Statistical Summary, 2004. General Election. Oregon Secretary of State Elections Division. http://www.sos.state.or.us/elections/nov22004/g04stats.pdf (April 8, 2010).

Tucker, Libby. 2008. Pot Bill in Oregon Gets Smoked in Special Session. Daily Journal of Commerce, February 21. 